\title{
The Centrality of Connectedness: A Conceptual Synthesis of Attending, Belonging, Engaging and Flowing
}

\author{
Terence Bowles ${ }^{1}$ and Janet Scull ${ }^{2}$ \\ ${ }^{1}$ Melbourne Graduate School of Education, University of Melbourne, Victoria, Australia and ${ }^{2}$ Faculty of Education, Monash \\ University, Melbourne, Victoria, Australia \\ Address for correspondence: Terence Bowles, Melbourne Graduate School of Education, The University of Melbourne, \\ 100 Leicester St, Carlton VIC 3053, Australia. Email: tbowles@unimelb.edu.au
}

(Received 11 July 2017; revised 10 June 2018; accepted 07 August 2018; first published online 07 September 2018)

\begin{abstract}
Over the past decade, researchers have called for a reconceptualisation of school connectedness. A review of literature between 1990 and 2016 was completed to define school connectedness and identified four factors: attending, belonging, engaging, and flow. The review of the published literature from 1990 to 2016 that related to the four factors was undertaken to define each of these terms and their relevance to school connectedness.

Subsequently, based on the four factors, a sequential, four-level model of school connectedness was proposed. The model suggests a progression from minimal connection to a deep level of acculturation and shared meaning relevant for adolescents between 12 and 18 years of age. It is argued that the four factors form the foundation for engagement and suggests the possibility of an experience of flow as a result of a student's connectedness with school. The literature on which the model is based draws together social, emotional, behavioural, and cognitive terms central to learning. The purpose of the review is to move beyond individual factors to propose an explanation for the sequence of graduated connection. Practically, the model provides a template for establishing the student's current experience of school to facilitate interventions to optimise connectedness with school.
\end{abstract}

Keywords: school connectedness; attending; belonging; engaging; flow; social and emotional learning

\section{Introduction: What is the Problem?}

School connection is an important protective factor for students, associated with reduced addictiveand substance-related issues, violence and gang involvement, as well as increased attendance and academic achievement (Centers for Disease Control and Prevention, 2009). However, researchers have noted the imbalance in the curriculum and the absence of interventions aimed to specifically increase students' perception of connection and belonging in the Australian context (Allen, Vella-Brodrick, \& Waters, 2016) and internationally (e.g., Centers for Disease Control \& Prevention, 2009). Despite the large body of literature available on enhancing classroom connectedness, more focused interventions aimed at promoting and evaluating school connectedness are required (Shochet, Dadds, Ham, \& Montague, 2006). The general aim of the current research is to propose a model of connectedness relevant for the development of programs and interventions by more precisely defining school connectedness. Despite the importance of connectedness, it has been described by an array of terms in the literature, especially within the school context (Barber \& Schluterman, 2008), ranging from 
performance-focused through to strictly social elements (Schulze \& Naidu, 2014). Connectedness has become interchangeable with a range of terms, including attachment (Allen, Hauser, Bell, \& O'Connor, 1994) and shared support, particularly of family members (Branje, van Aken, \& van Lieshout, 2002), and belonging (Allen \& Bowles, 2012), while some definitions emphasise the emotional and social aspects of being connected, such as Libbey's (2007) definition of school connectedness as a combination of feeling close to and a part of school, feeling safe, feeling that teachers care about and treat students fairly, and being happy at school. As noted by Barber and Schluterman (2008), historically, connectedness has been a poorly defined construct suffering an absence of precision in labelling, conceptualisation, and measurement. Little has changed to improve our understanding of connectedness in relation to these issues since that statement was made, whether considering connectedness generally or in the school context.

While there are factors and defining terms associated with the conception of connectedness, there is also considerable crossover with mixing of terms and factors associated with connectedness (Allen \& Bowles, 2012; Libbey, 2007). Aside from the clarity of the definition of connectedness, the multidimensional and sequential nature of connectedness is also of interest. This research explores the multidimensional and sequential aspects of school connectedness, with the aim of reordering and reconceptualising factors (in the literature), themes, and the defining terms of connectedness.

\section{The Definition of Connectedness}

Researchers have defined connectedness variously and contextually. Social psychology and communication scientists van Bel, Smolders, Ijsselsteijn, and de Kort, (2009, p. 67) define 'social connectedness as a short-term experience of belonging and relatedness, based on quantitative and qualitative social appraisals, and relationship salience'. Early definitions of school connectedness suggest that it is 'the extent to which students feel personally accepted, respected, included, and supported by others in the school social environment' (Goodenow, 1993, p. 80). A general definition of connectedness is 'the degree to which individuals experience the people and places in their lives as personally meaningful and important' (Schulze \& Naidu, 2014). Other aspects of connectedness are emphasised when the context is school; for example, the Wingspread Declaration (2004, p. 233) defines school connectedness as 'the belief by students that adults in the school care about their learning as well as about them as individuals'. Researchers of students and adolescents have defined connectedness as having '(1) a relational component, that is, the connection or bond that youth experience with socialising agents, and (2) an autonomy component, that is, the degree to which youth feel that their individuality is validated or supported by the socialising agents' (Barber \& Schluterman, 2008, p. 211). Importantly, while attempting to provide a general definition of connectedness associated with school settings, it can be argued that the autonomy-enhancing component can be replaced with a performative component. The main reasons for this are: (1) high-quality activities prime and prompt further high-quality activities and achievements that enhance autonomy and identity; (2) teachers and students have considerably more means of accessing and controlling performance and performative acts that may disrupt, enhance, and transform the student and their experience of learning (Enriquez, 2011); and (3) following the work of Derrida (1988) and Butler (2010) that common speech acts or the way students talk about 'their work' and how they represent and define their selves are performative. Performative acts contribute to the types of relationship, frequency of contact, and the distance between members of groups, as well as the size of the group and level of connectedness (e.g., friendship, class, school). Such acts, whether more specifically social, relational or academic, are markers of group cohesion, inclusion (Enriquez, 2011), and exclusion. The same complexity of connection is also reflected in extracurricular activities (McNeely, Nonnemaker, \& Blum, 2002). From this perspective, the definition of connectedness in this article is the degree that individuals perceive the people and places, experiences and activities in their lives are meaningful and important, in the present and for the future. Correspondingly, connectedness has two foci: a relational component and a performance/performative component. 


\section{Connectedness as a Multifactorial Construct}

To date, few authors have considered connectedness as a multidimensional construct. An exception to this is the work of Brown and Evans (2002), who provide a definition that exemplifies a multidimensional representation comprised of the four factors of commitment, power, belonging, and belief in rules. However, Brown and Evans' four factors are not sequential, and it is proposed that connectedness is both multidimensional and sequential, and can be separated into factors that are relational and performative. The first factor, attending, can be derived from terms highlighted in the Wingspread Declaration (2004). These include less absenteeism, higher student completion rates, and an improved school experience. The declaration also noted that connection was associated with positive adultstudent relationships, physical and emotional safety, and fewer incidents of fighting, bullying, or vandalism, which are related to the second factor of belonging. Both attendance and belonging are associated with relational aspects of Barber and Schluterman's (2008) definition of connectedness. The factor of engagement, derived from the Wingspread Declaration (2004), is related to high expectations and rigour, coupled with support for learning, increased motivation, increased classroom engagement, and increased academic performance. Accepting the more expansive definition provided by the three factors summarised from the Wingspread Declaration (2004), a fourth factor that is experienced far less commonly than the previous three but emerges at times after a student attends, feels as though they belong and is fully engaged, is described as transformative or transcendent, and is the experience of flow. Flow can be considered an extension of high levels of engagement. Csikszentmihalyi (1990) defines flow as 'the state in which people are so involved in an activity that nothing else seems to matter; the experience is so enjoyable that people will do it even at great cost, for the sheer sake of doing it' (p. 4). Hence, flow is the fourth factor of the proposed multifactorial model provided to comprehensively describe connectedness experienced by students in school.

\section{School Connectedness as a Sequential Process}

What is being proposed here is that the experience of connectedness can occur at various levels, each conditional on the satisfaction of the last, that is, that each of the four factors form a sequence beginning with attending. For some students, connecting to school is best described as being physically at school, being present or attending. Once a child attends physically and psychologically, they bring to the environment of the school the possibility of learning (Morrissey, Hutchison, \& Winsler, 2014), which includes learning with and about the self and others. Socialising opens the prospect of experiencing belonging as a student (Cemalcilar, 2010). It is difficult to conceive of a student belonging without attending in some manner, as even in situations of online learning or distance learning some presence has to occur before a person can be acknowledged. Once attending regularly, students can build identification with other students and the school, and start negotiating their space in the group and how they may belong (Strolin-Goltzman, Sisselman, Melekis, \& Auerbach, 2014). While it is possible to engage without belonging, or more likely with minimal belonging, optimal connectedness occurs when people feel as if they belong on a multitude of levels (St-Amand, Bowen, \& Lin 2017). Once the need to be social and belong is satisfied, and relations are up-building and affirming, the student can relax in the environment and be free to learn and engage (Libbey, 2004, 2007). Being connected with peers, teachers and the school community by engaging in planned activities brings a wider possibility of sense of reward, especially if accompanied with achievements (Appleton, Christenson, \& Furlong, 2008). Many students spend a large portion of their school life negotiating belonging, and this stage of connectedness may be dominant for them throughout their school life. Occasionally, when more engaged, when more affirmed within the community, and when fully present, the student may experience some sense of transformation or transcendance: flow (Shernoff, Csikszentmihalyi, Schneider, \& Shernoff, 2003). While a flow experience is likely to be infrequent in comparison to engagement, belonging and attending, it is possible that each time a student demonstrably strives or achieves extraordinarily well, or achieves a personal best (Hamari et al., 2016; Murcia, Gimeno, \& Coll, 2008), or expands the 
upper level of their zone of proximal development, they may experience flow (Basawapatna, Repenning, Koh, \& Nickerson, 2013).

A problem in the research on connectedness is that some terms defining the hypothetically sequential factors of attending, belonging, engaging, and flow were associated with more than one of the factors. Hence, further investigation of the definition of these factors to identify the core terms most frequently associated with each separate factor is necessary. The questions to be addressed in the remainder of this paper are:

1. Is there diversity in the factors and defining terms of connectedness that conceptually supports the independence of each of the four factors - attending, belonging, engaging, and flow?

2. What is the frequency of factors defining the four factors?

3. Can the four factors be defined and can themes be developed from the content of the defining terms to support the formation of a four-factor sequential model?

\section{Method}

The method used to approach the problem of defining the model of school connectedness was a combined deductive and inductive approach, based on the general theoretical principles of content analysis (Breckenridge, 2009; Corbin \& Strauss, 2015), which can be considered a general inductive approach to a narrative review of literature (Green, Johnson, \& Adams, 2001; Nightingale, 2009; Thomas, 2006). In this instance, the descriptive coding categories were identified a priori from previously published articles linking the four sequential factors of connectedness (a deductive method), and the defining of the terms associated with these four factors was an inductive analysis. According to Thomas (2006) inductive analysis:

refers to approaches that primarily use detailed readings of raw data to derive concepts, themes, or a model through interpretations made from the raw data by an evaluator or researcher.... Deductive analysis refers to data analyses that set out to test whether data are consistent with prior assumptions, theories, or hypotheses identified or constructed by an investigator. In practice, many evaluation projects use both inductive and deductive analysis. (p. 238)

The process was one of searching for the four factors and listing the factors and defining terms associated with each from the research literature. Following the process suggested by Corbin and Strauss (2015), defining terms were resorted to, to reduce crossover in the definition of the four factors. The terms were further categorised in themes, generated by reading and matching the defining terms. Here, the field of objects were published papers and the unit of analysis was the definition (defining terms) derived from the papers associated with the four terms constituting the categorical factors attending, belonging, engaging, and flowing. The searching process was followed by defining and sorting of the terms associated with the four factors, which was an inductive analysis. This iterative process was completed until the authors and a trained researcher achieved consensus. Any points of ambiguity were discussed until agreement was reached. This meant returning to the papers to check interpretations, and to enable the definitions of each term to be detailed and explicit (Pyett, 2003). This process is consistent with the recommendations of researchers in thematic analysis (Green et al., 2001; Nightingale, 2009; Nowell, Norris, White, \& Moules, 2017; Thomas, 2006) to build trustworthiness in the approach to the sorting and management of the data. A detailed outline of the process is provided in Figure 1.

To exemplify, searching 'Attending' brought up 'school attendance', with a defining term of 'at-risk attendance' from Hancock, Shepherd, Lawrence, and Zubrick (2013). It was coded negative (-) as this was a threat to attendance. The term 'at-risk attendance (-)' was subsequently regrouped with theme 1 , 'at risk of chronic absenteeism'. Similarly, 'at-risk behaviour (-)' (Glanville \& Wildhagen, 2007) was originally a defining term of 'Engaging'. However, this defining term was judged a better fit with 


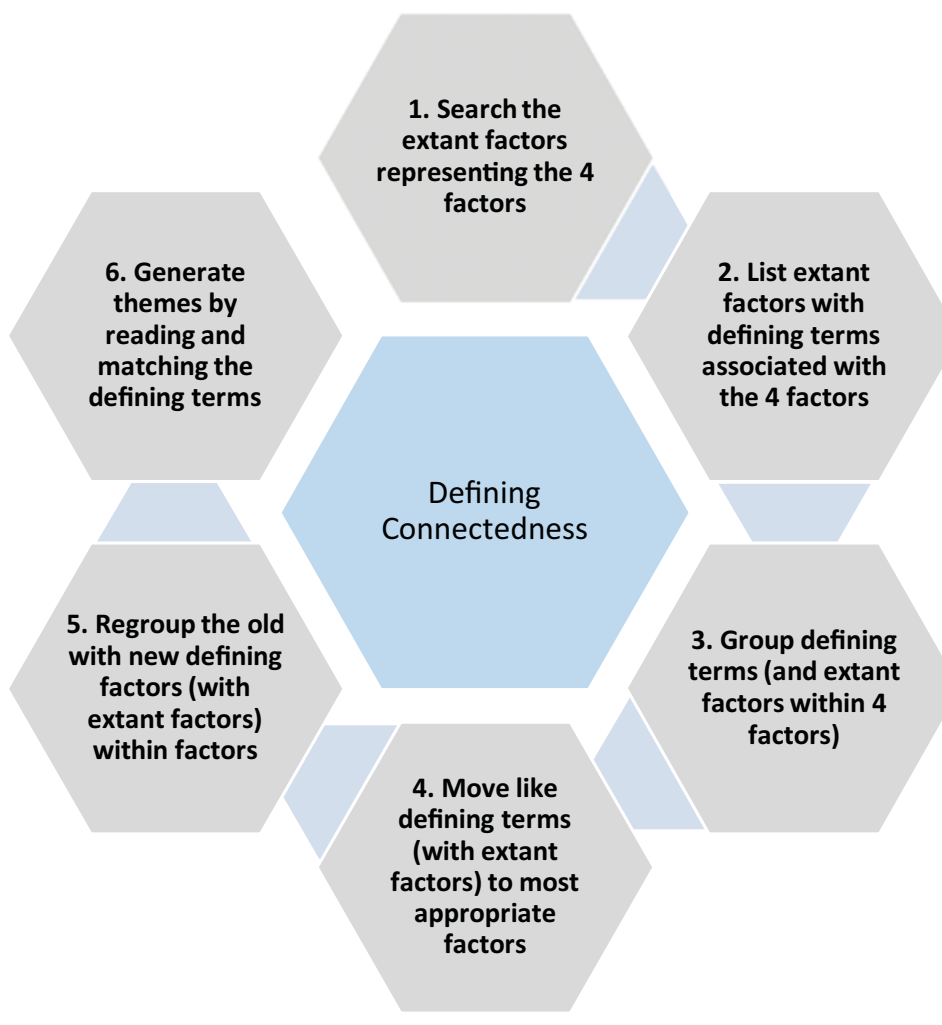

Figure 1. (Colour online) The process for defining connectedness.

'Attending', as 'at-risk behaviour' was considered a greater threat to a 'student's approach to routine attendance' (Attending: theme 3 ) because developing a routine to attend is a precondition for engagement.

A comprehensive search strategy was conducted to identify and retrieve relevant data. The inclusion/exclusion criteria were: papers published in a peer-reviewed journal only; searches completed on the most recent published work from after 1990; papers published in English; preference given to empirical studies, although conceptual studies were considered; positive and negative outcomes included; at least one of the terms connectedness, attending, belonging, engaging and flow (or another form of the term; e.g., attend, attending, attendance) or an associated term present and defined. To ensure that sufficient depth was obtained in generating the papers, a thorough search was conducted of the following databases: ERIC, EBSCO, PsychINFO, PubPsych, Social Sciences Citation Index, ProQuest, and Google Scholar. Keyword searches within each database included combinations of keywords with appropriate wildcards. Data saturation was assumed when no new data were emerging from further data searching (Fusch \& Ness, 2015; Marshall, Cardon, Poddar, \& Fontenot, 2013). What to count in considering saturation varies depending on the unit of analysis. In accordance with Marshall et al. (2013), when referring to phenomenological studies, saturation was shown to correspond with approximately 30 studies reviewed, and Charmaz (2014, p. 214) has recommended at least 25 interviews to claim saturation. In this research, the unit of analysis was the factor name and associated definition. As is commonly the case, some authors had multiple definitions, and some authors referred to or developed the definition of other authors, generating some overlap in the definitions. The search for independent defining terms associated with a factor found for attending $(n=32)$, belonging ( $n=44)$, engaging $(n=38)$, and flow $(n=43)$, at which point saturation was achieved. Further details of the independent factors and independent defining terms are summarised in Table 1. 
Table 1. Frequency Table of Independent Defining Terms of the Data Gathered

\begin{tabular}{lccc}
\hline Component sequential factors & $n$ of factors & $n$ of defining terms & $n$ of papers \\
\hline Relational & & & \\
\hline Attending & $6^{1}$ & 29 & 10 \\
\hline Belonging & 5 & 33 & 9 \\
\hline Performance/performative & & 13 & 40 \\
\hline Engaging & 1 & 40 & 10 \\
\hline Flowing & 26 & 142 & 11 \\
\hline Total & 13 & 40 \\
\hline
\end{tabular}

Note: ${ }^{1}$ Each factor and defining term are counted once.

\section{Results}

The Appendix shows the defining terms associated with the factors in alphabetical order within sorted themes. After grouping the defining terms and sorting them into the four factors, crossover was diminished and considerable diversity emerged with at least three themes defining each factor. Three major themes emerged for each of the factors associated with connectedness. The themes associated with attending were mainly about being present: student approach to routine attendance, disaffection and poor attendance, and at-risk and chronic absenteeism. The three themes that emerged from the terms associated with belonging were mainly about being among: positive experience of school, school-student aligned values, and positive student relationships. The third factor of engagement was also associated with three themes, mainly about being there to learn: involvement of the whole person, social support to focus on learning, and motivation and goal-direction to learn. Finally, flow is associated with being beyond the familiar, and involves: intense immersion, positive, peak rewarding activity, challenge, and achievement.

A relatively similar number of papers were distributed across the factors in this research (Table 1). Showing relative consistency was the number of independent defining terms that emerged from these papers. Fewer defining terms were apparent for attending, with more terms associated with belonging, and more again associated with engaging and flow. There was also variability in the number of factors. Interestingly, the sequential factor flow had only one factor. Belonging had five and attending had six factors. By comparison, there were 13 factors associated with engaging, possibly showing that this is the sequential factor with the greatest divergence.

Table 2 provides the summary definitions and the structure of multidimensional sequential factors of connection at school. As anticipated, the relational component is associated with attending and belonging. Performance/performative components were associated with engaging and flow. Each of the factors of attending, belonging, engaging, and flow was defined in simple terms and associated with at least three themes. So, each of the themes were independent of each other but contributed to the definition of the sequential factors. The four sequential factors defining connection were shown to be conceptually and definitionally separable and independent.

\section{Discussion}

In summary, in reference to the research questions, the analysis shows that the terms were quite divergent, and a core set of terms and factors could be related to each of the four sequential factors defining connectedness. The Appendix shows there was considerable variability in the number of factors associated with the four sequential factors, with a range of between 1 and 13 . The 142 terms could be allocated into the four sequential factors quite readily. There was some crossover indicated by the variety of 
Table 2. Definition of Connectedness to School by Factor and Theme

\begin{tabular}{|c|c|c|c|}
\hline Component sequential factors & Definition & Theme & Description \\
\hline \multicolumn{4}{|l|}{ Relational } \\
\hline \multirow[t]{4}{*}{ Attending } & Being present & & \\
\hline & & 1 & At-risk and chronic absenteeism \\
\hline & & 2 & Disaffection and poor attendance \\
\hline & & 3 & Student approach to routine attendance \\
\hline \multirow[t]{4}{*}{ Belonging } & Being with and among & & \\
\hline & & 1 & Positive experience of school \\
\hline & & 2 & School-student aligned values \\
\hline & & 3 & Positive student relationships \\
\hline \multicolumn{4}{|l|}{ Performance/performative } \\
\hline \multirow[t]{5}{*}{ Engaging } & Being there to learn & & \\
\hline & & 1 & Future and task focus \\
\hline & & 2 & Positive roles and models \\
\hline & & 3 & Planning and motivation \\
\hline & & 4 & Positive social engagement \\
\hline \multirow[t]{4}{*}{ Flowing } & Being beyond the familiar & & \\
\hline & & 1 & Intense immersion \\
\hline & & 2 & Positive, peak, rewarding activity \\
\hline & & 3 & Challenge and transcendent achievement \\
\hline
\end{tabular}

factors not being congruent with the sequential factors. This occurred because the terms were realigned with the new, sequential factors. The crossover was to be expected and was exemplified in the Hazel, Vazirabadi, and Gallagher (2013) reference in the table, where the defining term of 'belonging' was associated with 'Student school engagement' by the authors but was regrouped to the sequential factor of 'belonging'. While there was considerable crossover in the factors, indicating some porosity in the boundaries and definitions pre-existing in the literature, there remained a consistent core of factors and defining terms relevant to each sequential factor. This core could be categorised into three to four themes for each sequential factor of attending, belonging, engaging, and flow. It is hypothetically proposed that the factors form a sequence and a logical progression in the potential experience of students.

Attending may be characterised as being in the company of others, awareness of oneself and the context, such as school. At the simplest level it is 'being present'. Students who are among the least connected to school are those who are at risk and experiencing chronic absenteeism, which is the first theme. These students are among the most vulnerable in the community (Sherry, 2010) and may be suffering from multiple problems (Kearney, 2008a), yet once absenteeism is habituated for the student and for the school, they become somewhat invisible and less of an apparent problem. These students are also vulnerable to at-risk behaviour (Glanville \& Wildhagen, 2007) and need specialised attention, which is difficult to provide in a standard educational setting. Uncoupling from the routines of school can open the prospect of other habits that become preclusive of returning to school. Countering truancy is very difficult, showing that factors that reinforce attendance for the majority of students does not operate in the same way for those experiencing chronic school absence (Epstein \& Sheldon, 2002). However, there is a range of programs and interventions that have achieved some success in addressing 
truancy and chronic school absence (Maynard, McCrea, Pigott, \& Kelly, 2012). The second theme of 'Disaffection and poor attendance' is associated with feeling negative about school and frequent absence from school (Hancock et al., 2013) and therefore absence from routine (Morrissey et al., 2014) and programmatically dependent subjects, such as mathematics. This is a signifier point in connection to school and marks a need to focus attention on the specific child, which simultaneously removes anxiety and brings about discussion of the problem of non-attendance, while increasing the desirability of school as a place to be. Special attention needs to be paid to students who are vulnerable at this level so that they do not slip into school refusal. Interrupting chronic absenteeism has been shown to be related to specific types of rewards, the need to establish a contact person for parents to work with, workshops for parents and family members, and developing positive communication with families (Epstein \& Sheldon, 2002).

While building relationships and working towards the next sequential factor of belonging is valuable, it is also very important to focus on the generally welcoming nature of school and how it can be a secure and non-threatening, welcoming place - at the social/relational, emotional, behavioural, cognitive, and physical levels. Once a secure environment is experienced, routine attendance can be established. Hence, the third theme of 'Student approach to routine attendance' is characterised by liking school (Strolin-Goltzman et al., 2014) and attendance occurring without being overly apparent. This is the stage where attendance is not a conspicuous issue but is habituated as a positive experience, and energy can be given to participative aspects of attendance.

Belonging, like the concept of attending, had relatively similar independent defining terms and was sorted into relatively few $(n=5)$ factors, indicating that there was some diversity while gathering a core of factors. Belonging is dependent on the resolution of the issues associated with attending. Once a child is free of concerns and anxieties to do with attending, they start to develop a stronger awareness of 'being with' and a sense of relaxation and knowing that school is a sharing place of commonality with others. Hence, the first theme associated with belonging is about having a positive experience of school (Libbey, 2004). What draws children and people to belong varies on a number of dimensions, including gender, race, culture, and capabilities; prominent among these would be aligned interests and values, to name a few influential themes (St-Amand et al., 2017). Thus, the second theme of belonging is related to aligned values. The third theme gives prominence to positive student relations and the benefits such strong relationships might bring within school, as well as connecting the student with other families and communities (Cemalcilar, 2010; Grier-Reed, Appleton, Rodriguez, Ganuza, \& Reschly, 2012). For educational institutions, the point of belonging is to facilitate learning and the development of the whole student at least as much as emphasising social and community-building aspects of connection.

Engaging is a central issue for students in schools and is the first of the performance or performative components. There were twice as many factors associated with terms describing engaging than belonging or attending, indicating that there are many more ways of (describing) engaging and it is a more diffusely defined factor. It is the factor that forms the foundation for learning, hence it is appropriate that there is a broad array of ways of describing conceptualising and engaging in learning (Bowles \& Hattie, 2016). Research on engagement has focused on cognitive, behavioural and emotional engagement (Jimerson, Campos, \& Greif, 2003), and it is these three foundational dimensions of engagement that teachers are called upon to attend to in their teaching (Australian Institute of Teaching and School Leadership [AITSL], 2013). Maintaining a high level of engagement over a long period, linking the present and future through a task focus while at school is the first theme and is the responsibility of the student. This requires, behavioural, cognitive and emotional alignment, and engagement (Appleton et al., 2008; Jimerson et al., 2003) with school values, practices and processes. The influence of families, teachers and significant others to provide role models who embody, express, and model and nurture expectations about learning is the second theme (Grier-Reed et al., 2012; Hazel, Vazirabadi, \& Gallagher, 2013). Parents and the school and school staff conjointly are responsible for modelling and promoting these values, behaviours, and expectations. In many contexts, the most potentially influential and positive roles and models are the school staff and those involved in teacher-student relations 
(Strolin-Goltzman et al., 2014; Wingspread Declaration, 2004). The third theme is planning and motivation (Grier-Reed et al., 2012). Engaging requires planning for a student at a level at which they can be motivated to learn and assisted to understand. It is after such careful preparation and negotiation that learning can occur (Glanville \& Wildhagen, 2007) and motivation towards performance and outcomes can be maintained (Fredericks \& McColskey, 2012; Hazel et al., 2013). This is a conjoint space between learning, organising and creating (knowledge, objects, and performance) and is necessarily within the student and the psychological space between the student and teacher. The fourth factor of positive social engagement is about developing relationships with peers in various settings that resolve in generating greater engagement to and with the school, even though those activities may be extra-curricular or outside of school (Appleton et al., 2008; Fredericks \& McColskey, 2012). In short, no social relationship is frustrating or interfering with a positive level of social engagement with the student and their peers and their school, and these relations are enhancing the student's experience and level of engagement with the school and its culture (St-Amand et al., 2017). Importantly, while school education and learning is of central importance to the student, some students may be more engaged in extracurricular or out-of-school activities than school activities. Highpoints of these activities lead to levels of identification with others (past and present), the setting or physical context and the school, and provide the foundation for exceeding and transcending one's previous best performance or first experience. The object of schooling is socialisation and acculturation to allow for learning. When these things converge, there is a much higher prospect of achieving a flow experience.

Flow in the current research was typically described by only one factor - flow - and was associated with 40 defining terms, which is comparable to the other concepts. There appeared to be a confusion between the preconditions for flow and the experience of flow, prompting the need to differentiate engaging from the flow experience. Flow was associated with three themes in this research, and the first was intense immersion (Csikszentmihalyi, 1997). Positive, peak, and rewarding activity was the second theme (Clarke \& Haworth, 1994). The third theme was challenge and transcendent achievement level, where the achievement or performance level and the skill level are approximately equivalent (Ellis, Voelkl, \& Morris 1994; Ghani \& Deshpande, 1994). For flow to occur, the individual needs to be able to adapt, transform, and transcend the commonplace and see it anew in a richer and more profound fashion, allowing for both an immediate sense of positive affect and integrated and elated cognitive experience. Sometimes these are highly social events as well. Flow is an experience that is not often achieved and may provide experiences that are sustaining for decades or change the direction of someone's life. This sense of flow may be very transitory or fleeting but may be reinvoked after years, through various memories, symbols, insights, or emotions. Flow experiences are peak experiences, and in the ideal sense, it is less ego enhancing and gratifying than it is identity affirming and constructing.

The sequential aspects of the model express the transition from the individual who is alone and not connected with other students, though attending at school, to belonging, engaging and to the potential of flow experiences. The first stage suggests that students are attending and present (i.e., attending physically and psychologically: cognitively, emotionally, and behaviourally). Following the establishment and maintenance of the possibility to attend, the student may begin to belong. It is hard to belong and maintain relationships without attending. At the belonging stage, the attachment and nurturance needs are satisfied (and possibly corrected) sufficiently for the student to feel safe, secure, welcome, and valued. The security provided can permit contentment and relaxedness and an enjoyment of the security of the environment. It can also allow the student to feel energised, ready to more fully engage, and able to align with the school community, the staff, their values, intentions, and direction. To more agentically engage in most school activities an adolescent needs to focus on their learning and beyond: being present, feeling secure, being comfortable with being challenged to commit, engaging, and actively learning. Engagement is possibly as good as can be expected most of the time, for most students. Beyond this is flow, which is peak self-actualisation. The sequential nature of the relationship between these factors is hypothetical and dependent, as represented in Figure 2. 


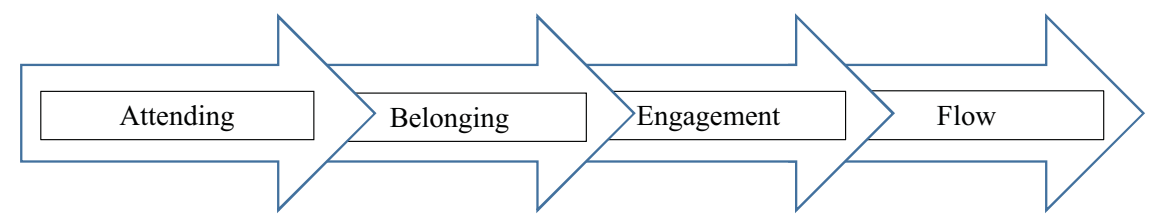

Figure 2. (Colour online) The sequence of four factors in the hypothesised model.

\section{Implications of the Research for Schools and Future Research}

Most specialists in schools dealing with issues associated with connectedness are helping students adjust to a process of accepting that physical (Epstein \& Sheldon 2002), psychological (Strolin-Goltzman et al., 2014), and cognitive attendance (Appleton, Christenson, Kim, \& Reschly, 2006) is necessary to fully belong within the school community and to be able to fully engage and experience the possibility of flow. According to McNeely \& Falci, 2004):

conventional connectedness involves connections to individuals who engage in prosocial behaviors and who regulate prosocial behavior in others. Unconventional connectedness, in contrast, involves connection to individuals who engage in behaviors that do not conform to prosocial norms. Thus, an adolescent's school connectedness will be conventional or unconventional depending on to whom an adolescent develops a connection. The type of connectedness will determine the direction of influence of school connectedness on health risk behaviors. (p. 291)

Unconventional, prosocial connection is worthy of further investigation, especially where schools seek to be inclusive by policy and practice, and respect and serve culturally and linguistically diverse groups, students from minority communities and those participating in alternative education systems. These principles are affirmed in inclusive education practices (Forlin, 2010) and multicultural policy (Australian Government, 2011). Finding a goodness-of-fit between adolescents, their school and community(ies) enhances student wellbeing, adjustment and development (Badura, Geckova, Sigmundova, van Dijk, \& Reijneveld, 2015; Forneris, Camiré, \& Williamson, 2015) and fits with SCT (Bandura, 2001, 2012). Once shunned by or self-alienating from an institution or group, adolescents will use similar processes to identify with and connect with alternative groups engaging in alternative and possibly antisocial behaviour (Brindle, 2016; Townsend, Fischer, \& King, 2007). Importantly, there is a limit to the degree of the connection an adolescent can make. Therefore, the more attending, belonging, and engaging with benign and benevolent groups and institutions that affirm prosocial and educational values that adolescents can connect with, the less time and resources adolescents have to be involved in and identify with malevolent, antisocial, and criminal groups. The more schools promote positive social support, diminish negative social support, and keep students on task to the various processes of schooling (educational, social, recreational and cultural), the better the academic outcomes (Bowles, 2008), which will enhance the prospect of engagement and promote the possibility of flow.

Just as connecting with school is important, so is disconnecting and leaving. Formally disconnecting from school may mean that a level of competence is reached where people can go to work or embark on another form of study or training, which is an adaptive process. Identifying stages in this process of disconnection and establishing whether it is the reverse of connection is important. It is necessary to explore the link between students who have a sense of violation as a result of association with schools (Brown, 2007) and those who attend but want to disengage or distance themselves (Gasper, DeLuca, \& Estacion, 2012), and whether this is associated with withdrawal and self-alienation (Schulze \& Naidu, 2014), followed by disorientation of self (De Stasio \& Di Chiacchio, 2015).

Future research investigating the definition and independence of the relationship between the four factors is necessary as the current research is descriptive. The four factors are hypothetically sequential. 
Future research should seek to establish (1) the level of association between sequential factors particularly adjacent factors - through further research, and (2) the sequential or the reciprocal nature of the hypothetically sequential factors needs to be explored in future research. While this conceptual framework has been developed with reference to adolescents in schools, the concepts are directly transferable into other relationships, such as those involved in friendships, romantic relationships through to committed couples, work relationships, and social groupings. The subsequent task for researchers is to develop definitions and models of connectedness that can be tested empirically and will inform best practice in the development of interventions relevant for adolescents, particularly in schools.

\section{References}

Allen, J.P., Hauser, S.T., Bell, K.L., \& O'Connor, T.G. (1994). Longitudinal assessment of autonomy and relatedness in adolescent-family interactions as predictors of adolescent ego development and self-esteem. Child Development, 65, 179-94.

Allen, K.A., \& Bowles, T. (2012). Belonging as a guiding principle in the education of adolescents. Australian Journal of Educational and Developmental Psychology, 12, 108-119.

Allen, K.A., Vella-Brodrick, D., \& Waters, L. (2016). Fostering school belonging in secondary schools using a socioecological framework. The Educational and Developmental Psychologist, 33, 97-121.

Appleton, J.J., Christenson, S.L., \& Furlong, M.J. (2008). Student engagement with school: Critical conceptual and methodological issues of the construct. Psychology in the Schools, 45, 369-386.

Appleton, J.J., Christenson, S.L., Kim, D., \& Reschly, A. (2006). Measuring cognitive and psychological engagement: Validation of the student engagement instrument. Journal of School Psychology, 44, 427-445. https://doi.org/10.1016/j. jsp.2006.04.002

Australian Government. (2011). The People of Australia: Australia's Multicultural Policy. Canberra, Australia Author. http:// www.immi.gov.au/media/publications/multicultural/pdf_doc/people-of-australia-multicultural-policybooklet.pdf

Australian Institute of Teaching and School Leadership (AITSL). (2013). Engagement in Australian schools (Research report). Melbourne, Australia: Author. Retrieved from http://www.aitsl.edu.au/docs/default-source/default-documentlibrary/engagement_in_australian_schools_grattan

Badura, P., Geckova, A.M., Sigmundova, D., van Dijk, J.P., \& Reijneveld, S.A. (2015). When children play, they feel better: Organized activity participation and health in adolescents. BioMed Central Public Health, 15, 1-8.

Bandura, A. (2001). Social cognitive theory: An agentic perspective. Annual Review of Psychology, 52, 1-26.

Bandura, A. (2012). Social cognitive theory. In P.A.M. Van Lange, A.W. Kruglanski, \& E.T. Higgins (Eds.), Handbook of theories of social psychology (vol. 1, pp. 349-373). Thousand Oaks, CA: Sage Publications.

Bakker, A.B. (2005). Flow among music teachers and their students: The crossover of peak experiences. Journal of Vocational Behavior, 66, 26-44. doi:10.1016/j.jvb.2003.11.001

Barber, B.K., \& Schluterman, J.M. (2008). Connectedness in the lives of children and adolescents: A call for greater conceptual clarity. Journal of Adolescent Health, 43, 209-216.

Basawapatna, A.R., Repenning, A., Koh, K.H., \& Nickerson, H. (2013, August). The zones of proximal flow: guiding students through a space of computational thinking skills and challenges. In Proceedings of the Ninth Annual International ACM Conference on International Computing Education Research (pp. 67-74).

Bowles, T. (2008). The relationship of time orientation with perceived academic performance and preparation for assessment in adolescents. Educational Psychology, 28, 551-565.

Bowles, T., \& Hattie, J. (2016). Seven motivating conceptions of learning of tertiary students. International Journal of Learning, Teaching and Educational Research, 15, 173-190.

Branje, S.J.T., van Aken, M.A.G., \& van Lieshout, C.F.M. (2002). Relational support in families with adolescents. Journal of Family Psychology, 16, 351-362.

Brown, R., \& Evans, W.P. (2002). Extracurricular activity and ethnicity: Creating greater school connection among diverse student populations. Urban Education, 37, 41-58.

Breckenridge, J. (2009). Demystifying theoretical sampling in grounded theory research. The Grounded Theory Review, 8, 113-125.

Brindle, K. (2016). Engagement in antisocial and risk-taking behaviours and the influence of adaptability and emotional dysregulation. Retrieved from University of Melbourne Theses database.

Brown, T.M. (2007). Lost and turned out: Academic, social, and emotional experiences of students excluded from school. Urban Education, 42, 432-455.

Butler, J. (2010). Performative agency. Journal of Cultural Economy, 3, 147-161. 
Cemalcilar, Z. (2010). Schools as socialisation contexts: Understanding the impact of school climate factors on students' sense of school belonging. Applied Psychology, 59, 243-272.

Centers for Disease Control and Prevention. (2009). School Connectedness: Strategies for Increasing Protective Factors Among Youth. Atlanta, GA: U.S. Department of Health and Human Services.

Charmaz, K.C. (2003). Grounded theory: Objectivist and constructivist methods. In N.K. Denzin \& Y.S. Lincoln (Eds.), Strategies of qualitative inquiry (2nd ed., pp. 249-291). Thousand Oaks, CA: Sage.

Charmaz, K.C. (2014). Constructing grounded theory (2nd ed.). Thousand Oaks, CA: Sage.

Corbin, J., \& Strauss, A. (2015). Basics of qualitative research: Techniques and procedures for developing grounded theory (4th ed.). Thousand Oaks, CA: Sage.

Clarke, S.G., \& Haworth, J.T. (1994). 'Flow' experience in the daily lives of sixth-form college students. British Journal of Psychology, 85, 511. Retrieved from http://search.proquest.com.ezp.lib.unimelb.edu.au/docview/1293609373?accountid=12372

Csikszentmihalyi, M. (1990). Flow: The psychology of optimal experience. New York: Harper Perennial.

Csikszentmihalyi, M. (1997). Finding flow: The psychology of engagement with everyday life. New York: Basic Books.

Derrida, J. (1988). Limited Inc. Evanston, IL: Northwestern University Press.

De Stasio, S., \& Di Chiacchio, C. (2015). Metacognitive and self-regulated learning strategies profiles: An exploratory survey of a group of high school students. Mediterranean Journal of Social Sciences, 6, 656-663.

De Wit, D.J., Karioja, K., \& Rye, B.J. (2010) Student perceptions of diminished teacher and classmate support following the transition to high school: are they related to declining attendance? School Effectiveness and School Improvement, 21, 451-472. doi:10.1080/09243453.2010.532010

Eccles, J.S., \& Templeton, J. (2002). Chapter 4: Extracurricular and other after-school activities for youth. Review of Research in Education, 26, 113-180.

Ellis, G.D., Voelkl, J.E., \& Morris, C. (1994). Measurement and analyses issues with explanation of variance in daily experience using the flow model. Journal of Leisure Research, 26, 256-337.

Enriquez, G. (2011). Embodying exclusion: The daily melancholia and performative politics of struggling early adolescent readers. English Teaching, 10, 90-112.

Epstein, J.L., \& Sheldon, S.B. (2002). Present and accounted for: Improving student attendance through family and community involvement. The Journal of Educational Research, 95, 308-318.

Forlin, C. (Ed.). (2010). Teacher education for inclusion: Changing paradigms and innovative approaches. Melbourne, Australia: Routledge.

Forneris, T., Camiré, M., \& Williamson, R. (2015). Extracurricular activity participation and the acquisition of developmental assets: Differences between involved and noninvolved Canadian high school students. Applied Developmental Science, 19, 47-55.

Fredericks, J.A., \& McColskey, W. (2012). The measurement of student engagement: A comparative analysis of various methods and student self-report instruments. In S. Christenson, A.L. Reschly, \& C. Wylie (Eds.), Handbook of research on student engagement (pp. 763-782). New York, NY: Springer.

Fusch, P.I., \& Ness, L.R. (2015). Are we there yet? Data saturation in qualitative research. The Qualitative Report, 20, 1408-1416.

Gasper, J., DeLuca, S., \& Estacion, A. (2012). Switching schools revisiting the relationship between school mobility and high school dropout. American Educational Research Journal, 49, 487-519.

Ghani, J.A., \& Deshpande, S.P. (1994). Task characteristics and the experience of optimal flow in human- computer interaction. The Journal of Psychology, 128, 381-391.

Glanville, J.L., \& Wildhagen, T. (2007). The measurement of school engagement: Assessing dimensionality and measurement invariance across race and ethnicity. Educational and Psychological Measurement, 67, 1019-1041.

Goodenow, C. (1993). The psychological sense of school membership among adolescents: Scale development and educational correlates. Psychology in the Schools, 30, 79-90.

Green, B.N., Johnson, C.D., \& Adams, A. (2001). Writing narrative literature reviews for peer-reviewed journals: Secrets of the trade. Journal of Sports Chiropractic and Rehabilitation, 15, 5-19.

Grier-Reed, T., Appleton, J., Rodriguez, M., Ganuza, Z., \& Reschly, A.L. (2012). Exploring the student engagement instrument and career perceptions with college students. Journal of Educational and Developmental Psychology, 2, 85-96.

Hagerty, B.M., Lynch-Sauer, J., Patusky, K.L., Bouwsema, M., \& Collier, P. (1992). Sense of belonging: A vital mental health concept. Archives of Psychiatric Nursing, 6, 172-177.

Hamari, J., Shernoff, D.J., Rowe, E., Coller, B., Asbell-Clarke, J., \& Edwards, T. (2016). Challenging games help students learn: An empirical study on engagement, flow and immersion in game-based learning. Computer and Human Behavior, 54, 170-179.

Hancock, K.J., Shepherd, C.C.J., Lawrence, D., \& Zubrick, S.R. (2013). Student attendance and educational outcomes: Every day counts (Report). Canberra, Australia: Department of Education, Employment and Workplace Relations.

Hazel, C.E., Vazirabadi, G.E., \& Gallagher, J. (2013). Measuring aspirations, belonging, and productivity in secondary students: Validation of the student school engagement measure. Psychology in the Schools, 50, 689-704. 
Jackson, S.A., \& Marsh, H.W. (1996). Development and validation of a scale to measure optimal experience: The flow state scale. Journal of Sport and Exercise Psychology, 18, 17-35.

Jimerson, S.R., Campos, E., \& Greif, J.L. (2003). Toward an understanding of definitions and measures of school engagement and related terms. California School Psychologist, 8, 7 - 27.

Kearney, C.A. (2008a). An interdisciplinary model of school absenteeism in youth to inform professional practice and public policy. Educational Psychology Review, 20, 257-282.

Kearney, C.A. (2008b). School absenteeism and school refusal behavior in youth: A contemporary review. Clinical Psychology Review, 28, 451-471.

Libbey, H.P. (2004). Measuring student relationships to school: Attachment, bonding, connectedness, and engagement. Journal of School Health, 74, 274-283.

Libbey, H.P. (2007). School connectedness: Influence above and beyond family connectedness (Doctoral dissertation). Retrieved from ProQuest Dissertations and Theses database. (UMI No. 3287822).

McNeely, C., \& Falci, C. (2004). School connectedness and the transition into and out of health-risk behavior among adolescents: A comparison of social belonging and teacher support. Journal of School Health, 74, 284-292.

McNeely, C.A., Nonnemaker, J.M., \& Blum, R.W. (2002). Promoting school connectedness: Evidence from the national longitudinal study of adolescent health. Journal of School Health, 72, 138-146.

Marshall, B., Cardon, P., Poddar, A., \& Fontenot, R. (2013). Does sample size matter in qualitative research? A review of qualitative interviews in is research. The Journal of Computer Information Systems, 54, 11-22.

Maynard, B.R., McCrea, K.T., Pigott, T.D., \& Kelly, M.S. (2012). Indicated truancy interventions for chronic truant students: A Campbell systematic review. Research on Social Work Practice, 23, 5-21.

Mills, M., \& McGregor, G. (2010). Re-engaging students in education: Success factors in alternative schools. Brisbane, Australia: Youth Affairs Network of Queensland (QUANQ).

Moffa, K., Dowdy, E., \& Furlong, M.J. (2016). Exploring the contributions of school belonging to complete mental health screening. The Educational and Developmental Psychologist, 33, 16-32.

Morrissey, T.W., Hutchison, L., \& Winsler, A. (2014). Family income, school attendance, and academic achievement in elementary school. Developmental Psychology, 50, 741-783.

Murcia, J.A.M., Gimeno, E.C., \& Coll, D.G.C. (2008). Relationships among goal orientations, motivational climate and flow in adolescent athletes: Differences by gender. The Spanish Journal of Psychology, 11, 181-191.

Nakamura, J., \& Csikszentmihalyi, M. (2002). The concept of flow. In C. R. Snyder \& S. J. Lopez (Eds.), Handbook of positive psychology (pp. 89-105). New York: Oxford University Press.

Nakamura, J., \& Csikszentmihalyi, M. (2014). The concept of flow. In M. Csikszentmihalyi (Ed.), Flow and the foundations of positive psychology (pp. 239-263). Dordrecht, Netherlands: Springer.

Nightingale, A. (2009). A guide to systematic literature reviews. Surgery (Oxford), 27, 381-384.

Nowell, L.S., Norris, J.M., White, D.E., \& Moules, N.J. (2017). Thematic analysis: Striving to meet the trustworthiness criteria. International Journal of Qualitative Methods, 16, 1-13.

Pyett, P.M. (2003). Validation of qualitative research in the 'real world.' Qualitative Health Research, 13, 1170-1179.

Reissner, V., Jost, D., Krahn, U., Knollmann, M., Weschenfelder, A. K., Neumann, A., . . Hebebrand, J. (2015). The treatment of school avoidance in children and adolescents with psychiatric illness-a randomized controlled trial. Deutsches Ärzteblatt International, 112, 655-662. doi:10.3238/arztebl.2015.0655

Roby, D.E. (2004). Research on school attendance and student achievement: A study of Ohio schools. Educational Research Quarterly, 28, 3-15.

Schulze, S., \& Naidu, N. (2014). Exploring the dependency of type of school and age with adolescent connectedness. Mediterranean Journal of Social Sciences, 5, 323-332.

St-Amand, J., Bowen, F., \& Lin, T.W.J. (2017). Le sentiment d'appartenance à l'école: une analyse conceptuelle. Canadian Journal of Education/Revue Canadienne de L'éducation, 40, 1-32.

Shochet, I.M., Dadds, M.R., Ham, D., \& Montague, R. (2006). School connectedness is an underemphasized parameter in adolescent mental health: Results of a community prediction study. Journal of Clinical Child and Adolescent Psychology, 35, $170-179$.

Shernoff, D.J., Csikszentmihalyi, M., Schneider, B., \& Shernoff, E.S. (2003). Student engagement in high school classrooms from the perspective of flow theory. School Psychology Quarterly, 18, 158-176.

Sherry, E. (2010). (Re) engaging marginalized groups through sport: The Homeless World Cup. International Review for the Sociology of Sport, 45, 59-71.

Strolin-Goltzman, J., Sisselman, A., Melekis, K., \& Auerbach, C. (2014). Understanding the relationship between schoolbased health center use, school connection, and academic performance. Health \& Social Work, 39, 83-91.

Tadich, B., Deed, C., Campbell, C., \& Prain, V. (2007). Student engagement in the middle years: A year 8 case study. Issues in Educational Research, 17, 256-271.

Thomas, D.R. (2006). A general inductive approach for analyzing qualitative evaluation data. American Journal of Evaluation, 27, 237-246. 
Townsend, L., Fischer, A. J., \& King, G. (2007). A systematic review of the relationship between high school dropout and substance use. Clinical Child and Family Psychology, 10, 295-315.

van Bel, D. T., Smolders, K.C.H. J., Ijsselsteijn, W., \& de Kort, Y.A.W. (2009). Social connectedness: concept and measurement. Intelligent Environments, 2, 67-74.

Wingspread, Declaration. (2004). Wingspread declaration on school connections. Journal of School Health, 74, $233-234$.

\section{Appendix}

\section{Factors and Themes, Based on the Defining Terms and Exemplars, Defining the Concepts of Connectedness, and Corresponding Factors}

\begin{tabular}{|c|c|c|c|}
\hline $\begin{array}{l}\text { Sequential factors } \\
\text { Factor }\end{array}$ & Theme & Defining terms & Authors \\
\hline \multicolumn{4}{|l|}{ Attending } \\
\hline School avoidance & 1 & & Reissner et al. (2015) \\
\hline School attendance & 1 & At-risk attendance $(-)$ & $\begin{array}{l}\text { Hancock, Shepherd, Lawrence, } \\
\text { \& Zubrick (2013) }\end{array}$ \\
\hline Engagement & 1 & At-risk behaviour (-) & Glanville \& Wildhagen (2007) \\
\hline School attendance & 1 & Chronic absence (-) & Hancock et al. (2013) \\
\hline Attendance & 1 & Chronic absenteeism (-) & Epstein \& Sheldon (2002) \\
\hline School attendance & 1 & Chronic truancy (-) & Hancock et al. (2013) \\
\hline School attendance & 1 & Persistent absenteeism (-) & Hancock et al. (2013) \\
\hline Absenteeism & 1 & School phobia (-) & Kearney (2008a, 2008b) \\
\hline Absenteeism & 1 & School refusal (-) & Kearney (2008a, 2008b) \\
\hline School attendance & 1 & Severe non-attendance $(-)$ & Hancock et al. (2013) \\
\hline (Re)-engagement & 1 & Social disadvantage $(-)$ & Sherry (2010) \\
\hline (Re)-engagement & 1 & Social exclusion $(-)$ & Sherry (2010) \\
\hline Absenteeism & 1 & Truancy (-) & Kearney (2008a) \\
\hline (Non-)attendance & 1 & Withdrawal (-) & De Wit, Karioja, \& Rye (2010) \\
\hline Attendance & 2 & Absence (-) & $\begin{array}{l}\text { Morrissey, Hutchison, } \\
\text { \& Winsler (2014) }\end{array}$ \\
\hline Attendance & 2 & Absence of routines $(-)$ & Morrissey et al. (2014) \\
\hline School attendance & 2 & Authorized absence (-) & Hancock et al. (2013) \\
\hline (Non-)attendance & 2 & Disaffection (-) & De Wit et al. (2010) \\
\hline Absenteeism & 2 & Number of days absent from school (-) & Kearney (2008a) \\
\hline Attendance & 2 & Poor attendance $(-)$ & Morrissey et al. (2014) \\
\hline (Non-)attendance & 2 & Student learning time loss $(-)$ & Roby (2004) \\
\hline Attendance & 2 & Tardiness (-) & Morrissey et al. (2014) \\
\hline School attendance & 2 & Unauthorized absence (-) & Hancock et al. (2013) \\
\hline $\begin{array}{l}\text { Behavioural } \\
\text { engagement }\end{array}$ & 3 & Adhering to rules & Fredericks \& McColskey (2012) \\
\hline Engagement & 3 & Attendance & Glanville \& Wildhagen (2007) \\
\hline $\begin{array}{l}\text { Behavioural } \\
\text { engagement }\end{array}$ & 3 & Attending class & Fredericks \& McColskey (2012) \\
\hline
\end{tabular}




\begin{tabular}{|c|c|c|c|}
\hline \multicolumn{4}{|l|}{ Sequential factors } \\
\hline Factor & Theme & Defining terms & Authors \\
\hline Attendance & 3 & Daily attendance & Epstein \& Sheldon (2002) \\
\hline (Non-)attendance & 3 & $\begin{array}{l}\text { Declining significance of school } \\
\& \text { teachers }(-)\end{array}$ & De Wit et al. (2010) \\
\hline (Re)-engagement & 3 & Flexible learning & Mills \& McGregor (2010) \\
\hline School bonding & 3 & Like going to school & Strolin-Goltzman, et al. (2014) \\
\hline (Re)-engagement & 3 & Non-compulsory attendance & Mills \& McGregor (2010) \\
\hline (Non-)attendance & 3 & Not receiving emotional support (-) & De Wit et al. (2010) \\
\hline \multicolumn{4}{|l|}{ Belonging } \\
\hline School connectedness & 1 & A part of & Libbey (2007) \\
\hline $\begin{array}{l}\text { Student school } \\
\text { engagement }\end{array}$ & 1 & Belonging & Hazel et al. (2013) \\
\hline School connectedness & 1 & Feel as if you belong and are cared for & $\begin{array}{l}\text { McNeely, Nonnemaker } \\
\text { \& Blum, (2002) }\end{array}$ \\
\hline Positive orientation & 1 & Feel Positive about school & Libbey (2004) \\
\hline School connectedness & 1 & Feeling close to & Libbey (2007) \\
\hline School connectedness & 1 & Feeling that teachers care about students & Libbey (2007) \\
\hline School connectedness & 1 & Happy at school & Libbey (2007) \\
\hline School bonding & 1 & Happy at school & Strolin-Goltzman et al. (2014) \\
\hline School bonding & 1 & Likes school & Strolin-Goltzman et al. (2014) \\
\hline Belonging & 1 & Positive emotion toward the school & St-Amand, Bowen, \& Lin (2017) \\
\hline School connectedness & 1 & Social Belonging & McNeely \& Faici (2004) \\
\hline School bonding & 1 & Welcome at school & Strolin-Goltzman et al. (2014) \\
\hline Belonging & 2 & $\begin{array}{l}\text { (Harmonization), similarity, with teachers } \\
\text { and peers }\end{array}$ & St-Amand et al. (2017) \\
\hline Belonging & 2 & $\begin{array}{l}\text { Perception of involvement in a social } \\
\text { system }\end{array}$ & Hagerty et al. (1992) \\
\hline School attachment & 2 & Respect & Strolin-Goltzman et al. (2014) \\
\hline School attachment & 2 & Safety & Strolin-Goltzman et al. (2014) \\
\hline Flowing & 2 & School identification & Libbey (2004) \\
\hline School connectedness & 2 & Students feel safe at school & Wingspread Declaration (2004) \\
\hline School connectedness & 2 & Students feeling safe at school & Libbey (2007) \\
\hline Belonging & 2 & Violence in school (-) & Cemalcilar (2010) \\
\hline School attachment & 3 & & Libbey (2004) \\
\hline School bonding & 3 & & Libbey (2004) \\
\hline Belonging & 3 & Administrator/student relations & Cemalcilar (2010) \\
\hline School connectedness & 3 & Adults are interested in them as individuals & Wingspread Declaration (2004) \\
\hline School connectedness & 3 & $\begin{array}{l}\text { Adults in school community care about } \\
\text { learning }\end{array}$ & Wingspread Declaration (2004) \\
\hline Belonging & 3 & Peer relations & Cemalcilar (2010) \\
\hline
\end{tabular}




\begin{tabular}{|c|c|c|c|}
\hline \multicolumn{4}{|l|}{ Sequential factors } \\
\hline Factor & Theme & Defining terms & Authors \\
\hline Student engagement & 3 & Peer Support at School & Grier-Reed et al. (2012) \\
\hline Belonging & 3 & $\begin{array}{l}\text { Positive social relations with school } \\
\text { community }\end{array}$ & St-Amand et al. (2017) \\
\hline School connectedness & 3 & Positive teacher-student relationships & Wingspread Declaration (2004) \\
\hline School attachment & 3 & Relationships & Strolin-Goltzman et al. (2014) \\
\hline Emotional engagement & 3 & Relationships with and between students & Fredericks \& McColskey (2012) \\
\hline Emotional engagement & 3 & Relationships with teachers & Fredericks \& McColskey (2012) \\
\hline Engagement & 3 & Relationships with teachers & Glanville \& Wildhagen (2007) \\
\hline Belonging & 3 & School satisfaction & $\begin{array}{l}\text { Moffa, Dowdy, \& Furlong } \\
(2016)\end{array}$ \\
\hline (Re)-engagement & 3 & Social capital & Sherry (2010) \\
\hline Attendance & 3 & Student support & De Wit et al. (2010) \\
\hline Belonging & 3 & Supportive resources & Cemalcilar (2010) \\
\hline Attendance & 3 & Teacher support & De Wit et al. (2010) \\
\hline School connectedness & 1 & Teacher support & McNeely \& Faici (2004) \\
\hline Engagement & 3 & Teacher support & Libbey (2004) \\
\hline School connectedness & 3 & Teachers treat them fairly & Libbey (2007) \\
\hline Belonging & 3 & Teacher-student relations & Cemalcilar (2010) \\
\hline Student engagement & 3 & Teacher-student relationships & Grier-Reed et al. (2012) \\
\hline Belonging & 3 & The physical environment & Cemalcilar (2010) \\
\hline \multicolumn{4}{|l|}{ Engaging } \\
\hline $\begin{array}{l}\text { Student school } \\
\text { engagement }\end{array}$ & 1 & Aspirations & Hazel et al. (2013) \\
\hline Student engagement & 1 & Behavioural engagement & Jimerson et al. (2003) \\
\hline Student engagement & 1 & Behavioural engagement & Appleton et al. (2008) \\
\hline Student engagement & 1 & Cognitive engagement & Jimerson et al. (2003) \\
\hline Student engagement & 1 & Cognitive engagement & Appleton et al. (2008) \\
\hline Student engagement & 1 & Emotional engagement & Jimerson et al. (2003) \\
\hline Student engagement & 1 & Emotional engagement & Appleton et al. (2008) \\
\hline Engagement & 1 & Extrinsic motivation & Glanville \& Wildhagen (2007) \\
\hline Student engagement & 1 & Future aspirations and goals & Grier-Reed et al. (2012) \\
\hline Commitment & 1 & Future focused & Strolin-Goltzman et al. (2014) \\
\hline Commitment & 1 & Goal focused & Strolin-Goltzman et al. (2014) \\
\hline Engagement & 1 & School engagement & Appleton et al. (2008) \\
\hline Engagement & 1 & Student engagement & Appleton et al. (2008) \\
\hline School connectedness & 2 & Adults have high academic expectations & Wingspread Declaration (2004) \\
\hline Commitment & 2 & Adults help me understand & Strolin-Goltzman et al. (2014) \\
\hline
\end{tabular}




\begin{tabular}{|c|c|c|c|}
\hline \multicolumn{4}{|l|}{ Sequential factors } \\
\hline Factor & Theme & Defining terms & Authors \\
\hline Aspirations & 2 & Family can help with homework & Hazel et al. (2013) \\
\hline Student engagement & 2 & Family support for learning & Grier-Reed, et al. (2012) \\
\hline Engagement & 2 & Teacher perceptions & Glanville \& Wildhagen (2007) \\
\hline Disengagement (-) & 3 & $\begin{array}{l}\text { Absence of generative, adaptive learning } \\
\text { strategies }\end{array}$ & $\begin{array}{l}\text { Tadich, Deed, Campbell, } \\
\text { \& Prain (2007) }\end{array}$ \\
\hline Engagement & 3 & Academic interest & Glanville \& Wildhagen (2007) \\
\hline $\begin{array}{l}\text { Behavioural } \\
\text { engagement }\end{array}$ & 3 & Completing tasks & Fredericks \& McColskey (2012) \\
\hline Student engagement & 3 & Control and Relevance of School Work & Grier-Reed et al. (2012) \\
\hline Aspirations & 3 & Getting good grades (is important to me) & Hazel et al. (2013) \\
\hline Engagement & 3 & Participation identification & Appleton et al. (2008) \\
\hline Engagement & 3 & Preparation & Glanville \& Wildhagen (2007) \\
\hline $\begin{array}{l}\text { Student school } \\
\text { engagement }\end{array}$ & 3 & Productivity & Hazel et al. (2013) \\
\hline Cognitive engagement & 3 & $\begin{array}{l}\text { Psychological investment } \\
\text { (in student's learning) }\end{array}$ & Fredericks \& McColskey (2012) \\
\hline Engagement & 3 & Student engagement in academic work & Appleton et al. (2008) \\
\hline Productivity & 3 & Student knows how to study for tests & Hazel et al. (2013) \\
\hline School engagement & 4 & & Libbey (2004) \\
\hline School involvement & 4 & & Libbey (2004) \\
\hline Engagement & 4 & & Appleton et al. (2008) \\
\hline Engagement & 4 & Academic engagement & Appleton et al. (2008) \\
\hline Belonging & 4 & $\begin{array}{l}\text { Active involved in the classroom/school } \\
\text { activities }\end{array}$ & St-Amand et al. (2017) \\
\hline Engagement & 4 & Engagement in school work & Appleton et al. (2008) \\
\hline $\begin{array}{l}\text { Behavioural } \\
\text { engagement }\end{array}$ & 4 & Extracurricular activities & Fredericks \& McColskey (2012) \\
\hline Engagement & 4 & Participation in out of school activities & Eccles \& Templeton (2002) \\
\hline Engagement & 4 & Student engagement in/with school & Appleton et al. (2008) \\
\hline \multicolumn{4}{|l|}{ Flow } \\
\hline Flow & 1 & Absorption/total immersion & Csikszentmihalyi (1997) \\
\hline Flow & 1 & Centering & Csikszentmihalyi (1990) \\
\hline Flow & 1 & Clarity & Csikszentmihalyi (1990) \\
\hline Flow & 1 & Concentration & Shernoff et al. (2003) \\
\hline Flow & 1 & $\begin{array}{l}\text { Enjoyment from total concentration } \\
\text { in an activity }\end{array}$ & Ghani \& Deshpande (1994) \\
\hline Flow & 1 & High cognitive involvement & Shernoff et al. (2003) \\
\hline Flow & 1 & Intense and focused concentration & $\begin{array}{l}\text { Nakamura \& Csikszentmihalyi } \\
\text { (2014) }\end{array}$ \\
\hline
\end{tabular}




\begin{tabular}{|c|c|c|c|}
\hline \multicolumn{4}{|c|}{ Sequential factors } \\
\hline Factor & Theme & Defining terms & Authors \\
\hline Flow & 1 & Intense focus & Csikszentmihalyi (1990) \\
\hline Flow & 1 & Intense involvement in an activity & Csikszentmihalyi (1990) \\
\hline Flow & 1 & Loss of reflective self- consciousness & $\begin{array}{l}\text { Nakamura \& Csikszentmihalyi } \\
\text { (2014) }\end{array}$ \\
\hline Flow & 1 & Loss of self-consciousness & Jackson \& Marsh (1996) \\
\hline Flow & 1 & Total concentration & Jackson \& Marsh (1996) \\
\hline Flow & 1 & Total concentration in an activity & Ghani \& Deshpande (1994) \\
\hline Flow & 1 & $\begin{array}{l}\text { Total immersion resulting intense } \\
\text { enjoyment }\end{array}$ & Bakker (2005) \\
\hline Flow & 1 & Transformation of time & Jackson \& Marsh (1996) \\
\hline Flow & 2 & Action-awareness merging & Jackson \& Marsh (1996) \\
\hline Flow & 2 & Enjoyment & Csikszentmihalyi (1990) \\
\hline Flow & 2 & Enjoyment & Csikszentmihalyi (1997) \\
\hline Flow & 2 & Enjoyment & Shernoff et al. (2003) \\
\hline Flow & 2 & Enjoyment derived from the activity & Ghani \& Deshpande (1994) \\
\hline Flow & 2 & Enjoyment in the experience & Jackson \& Marsh (1996) \\
\hline Flow & 2 & Interest & Shernoff et al. (2003) \\
\hline Flow & 2 & $\begin{array}{l}\text { Optimal experience, high cognitive } \\
\text { involvement }\end{array}$ & Clarke \& Haworth (1994) \\
\hline Flow & 2 & Optimal experienced & Shernoff et al. (2003) \\
\hline Flow & 2 & Peak experience (from a range of activities) & Csikszentmihalyi (1997) \\
\hline Flow & 2 & Positive affect & Ellis, Voelkl, \& Morris (1994) \\
\hline Flow & 3 & Activity as intrinsically rewarding & $\begin{array}{l}\text { Nakamura \& Csikszentmihalyi } \\
\text { (2014) }\end{array}$ \\
\hline Flow & 3 & Activity is worth doing for its own sake & $\begin{array}{l}\text { Nakamura \& Csikszentmihalyi } \\
(2002)\end{array}$ \\
\hline Flow & 3 & Arousal & Ellis et al. (1994) \\
\hline Flow & 3 & Challenge & Csikszentmihalyi (1990) \\
\hline Flow & 3 & Challenge relative to skill level & Ghani \& Deshpande (1994) \\
\hline Flow & 3 & Challenge-skill balance & Jackson \& Marsh (1996) \\
\hline Flow & 3 & Choice & Csikszentmihalyi (1990) \\
\hline Flow & 3 & Clear goals & Jackson \& Marsh (1996) \\
\hline Flow & 3 & Commitment & Csikszentmihalyi (1990) \\
\hline Flow & 3 & Commitment & Strolin-Goltzman et al. (2014) \\
\hline Flow & 3 & Intrinsic motivation & Csikszentmihalyi (1997) \\
\hline Flow & 3 & Intrinsic motivation & Ellis et al. (1994) \\
\hline Flow & 3 & $\begin{array}{l}\text { Optimal challenge corresponding } \\
\text { to skill level }\end{array}$ & Ghani \& Deshpande (1994) \\
\hline
\end{tabular}




\begin{tabular}{ccll}
\hline $\begin{array}{l}\text { Sequential factors } \\
\text { Factor }\end{array}$ & Theme & Defining terms & Authors \\
\hline Flow & 3 & Optimal performance: challenge equals skill & Ellis et al. (1994) \\
\hline Flow & 3 & Sense of control & Jackson \& Marsh (1996) \\
\hline Flow & 3 & Sense that one can control one's actions & $\begin{array}{l}\text { Nakamura \& Csikszentmihalyi } \\
(2014)\end{array}$ \\
\hline Flow & 3 & Unambiguous feedback & Jackson \& Marsh (1996) \\
\hline
\end{tabular}

Note: Data in the table sorted by theme (numerical order) and defining terms (alphabetical order) after the terms were inductively sorted within and across factors.

Cite this article: Bowles T and Scull J (2019). The Centrality of Connectedness: A Conceptual Synthesis of Attending, Belonging, Engaging and Flowing. Journal of Psychologists and Counsellors in Schools 29, 3-21. https://doi.org/10.1017/ jgc. 2018.13 